\title{
Developing Resilience to Emergencies: Evaluation of Thermal Indices and Outdoor Comfort Before and During the COVID-19 Pandemic
}

\author{
Timothy O. Adekunle *t \\ Department of Architecture, College of Engineering, Technology and Architecture (CETA), University of Hartford, West Hartford, \\ CT, United States
}

OPEN ACCESS

Edited by:

Ljubomir Jankovic,

University of Hertfordshire,

United Kingdom

Reviewed by:

Purvesh Bharadwaj, University of Hertfordshire,

United Kingdom

Hourakhsh Ahmad Nia,

Alanya Hamdullah Emin Pasa

University, Turkey

Tom Dolan,

University College London, United Kingdom

${ }^{*}$ Correspondence:

Timothy O. Adekunle

adekunle@hartford.edu

tORCID:

Timothy O. Adekunle orcid.org/0000-0001-6738-5548

\section{Specialty section: \\ This article was submitted to \\ Urban Science, \\ a section of the journal}

Frontiers in Built Environment

Received: 27 August 2021

Accepted: 19 October 2021

Published: 23 November 2021

Citation:

Adekunle TO (2021) Developing Resilience to Emergencies: Evaluation

of Thermal Indices and Outdoor Comfort Before and During the COVID-

19 Pandemic.

Front. Built Environ. 7:765752.

doi: 10.3389/fbuil.2021.765752
This research discusses thermal indices and outdoor comfort before and during the Coronavirus Disease of 2019 (COVID-19) pandemic in three counties in Connecticut $\left(41.6032^{\circ} \mathrm{N}, 73.0877^{\circ} \mathrm{W}\right)$, United States. The counties are Fairfield, Hartford, and New Haven. Existing research noted that people residing in highly populated urban and lowincome areas are disproportionately affected by the pandemic and subject to health, heat, and cold stress-related problems. As a result, the study is motivated to examine outdoor comfort and thermal indices in the counties that account for over $75 \%$ of the population in the state. The specific aim of the study is to examine outdoor comfort and thermal indices a year before and during the pandemic to determine if the pandemic significantly affects outdoor occupants and their overall well-being. Due to lesser activities observed during the pandemic than before the pandemic, the research questions include 1) Does the pandemic year provide a more comfortable thermal environment for outdoor occupants than the period before the pandemic? 2) Does the period provide a cleaner environment with no thermal or cold stress to occupants than before the pandemic? The research approaches include the field data recorded in 2019 and 2020. The research also utilized observations and mathematical models. The findings revealed that the mean monthly temperatures varied from $-3.2^{\circ} \mathrm{C}$ to $25.2^{\circ} \mathrm{C}$ and relative humidity ranged from and $62.6-70.7 \%$. The study revealed cold stress in wintertime, especially in Fairfield. Heat stress is also noted in summertime across the counties. New Haven is more prone to heat stress than other counties because of some factors (such as climate change, lesser land area, higher incidence from solar radiation, etc.). Higher thermal indices are reported in 2020 (during the pandemic) than the indices computed for 2019 (pre-pandemic) which could influence thermal comfort, health, and well-being of people. The indices are strongly influenced by outdoor temperatures and dew-point. A combination of some environmental variables such as temperature and wind speed also have significant effects on the indices. The study recommends that the use of clean energy for running infrastructure systems would help in mitigating the impact of climate change in various locations. The investigation suggests that a thorough evaluation of environmental conditions and interventions should be explored for developing resilience to emergencies in cities and urban areas. The research 
outcomes provide useful information for designers, planners, stakeholders, policymakers, etc., to develop pathways for achieving resilient zero-carbon cities in various places.

Keywords: thermal indices, outdoor comfort, resilience, climate change, environmental variables, urban areas, COVID-19 pandemic

\section{INTRODUCTION}

The World Health Organization (WHO) referred to the COVID19 pandemic as a global emergency and it requires an innovative approach to mitigate (WHO, 2020). The pandemic has impacted the entire globe and changed how we interact, conduct businesses amongst others (UN, 2020; WHO, 2020). Additionally, the daily operations in many offices, organizations, and cities have been either re-organized, reduced, or close due to the various restrictions and guidelines to keep everyone safe (United Nations-UN, 2020; WHO, 2020). The pandemic has led to many fatalities and cases across the world, especially in highly populated cities and low-income neighbourhoods. It has also brought many lessons and created opportunities for further research on comfort, health, and well-being of people in different thermal spaces (UN, 2020; WHO, 2020). As a result, the investigation is developed to assess the outdoor comfort and well-being of occupants in various metropolises in the study area.

This study intends to contribute to the on-going discussions on developing resilience to emergencies by assessing outdoor comfort and thermal indices before and during the COVID-19 pandemic in three counties in the Northeast of the United States. The specific purpose of the study is to examine outdoor comfort and thermal indices a year before and during the pandemic to determine if the pandemic significantly influences outdoor occupants and their overall well-being. The principal goals of the study are-to understand various parameters influencing outdoor comfort before and during the pandemic in the most populated counties. The study also aims to examine strategies that can be explored for developing resilience to emergencies in the thermal environment which are critical for actualizing pathways to resilient zero-carbon cities across the world. Due to lesser activities reported during the pandemic than before the pandemic, the research questions include 1) Does the pandemic year provide a more comfortable thermal environment for outdoor occupants than the period before the pandemic? 2) Does the period provide a cleaner environment with no thermal or cold stress to occupants than before the pandemic? The main objectives of the study include:

1) To gather outdoor environmental data for 1 year before and during the COVID-19 pandemic in the study areas for evaluation.

2) To identify the effect of these parameters on the thermal comfort of occupants in the study locations.

3) To discuss the important variables influencing outdoor comfort and identify approaches for developing resilience to emergencies that are crucial for achieving pathways to resilient zero-carbon cities.
4) To make recommendations and provide useful information for designers, planners, policymakers, and stakeholders that could advance the initiatives for realizing zero-carbon cities.

Developing resilience to emergencies in municipalities across the world is critical towards attaining zero-carbon cities in different locations and climates. Existing research discussed that in many advanced countries such as the United States, approximately $80 \%$ of the people live in cities (US Census Bureau, 2013; Martin, 2015). Generally, cities are complex and mutually dependent systems (Godschalk, 2003). They are also prone to threats from humans and nature (Godschalk, 2003; Martin, 2015). These threats include climate change, environmental pollution, etc.

\section{LITERATURE REVIEW}

\subsection{Cities and Urban Heat Islands}

Cities consist of infrastructures, resources, and human activities that make them desirable and liveable (Dwyer et al., 2004). Among the characteristics that make cities desirable and feasible include their high populations, different structures with architectural features, places for people to meet, interconnected infrastructure systems (Godschalk, 2003; Dwyer et al., 2004). Cities also provide growth opportunities in many areas. Moreover, cluster infrastructure may also increase cities' vulnerability to the disruptive impacts associated with natural disasters (hurricanes, flood, earthquake, etc.), attacks from terrorists (Godschalk, 2003), urban heat island (UHI) effects usually caused by the design of the built environment and aggravated by climate change (Gago et al., 2013; Environmental Protection Agency-EPA, 2020a), noise pollution (de Paiva Vianna et al., 2015), poor environmental conditions (Torrey, 2004) including air quality (EPA, 2020b), thermal discomfort (Emmanuel, 2005), sound discomfort (Chepesiuk, 2005), and visual discomfort (Alkhalifa et al., 2018).

Existing research evaluated the effect of anthropogenic climate change and human actions on our environment and ecosystems (Mahmoud and Gan, 2018). The study found out that human actions, industrial development, deforestation, land use modification, and change in greenhouse gases had noticeable effects on the environment and ecosystem services. According to the National Geographic Society (2021), human beings have impacted the environment in numerous ways such as pollution, deforestation, overpopulation, burning fossil fuels, etc. The changes have led to poor quality of air, soil erosion, climate change, water contamination, and others. Additionally, the changes have led to increasing temperatures in urban and 


\section{A}

B
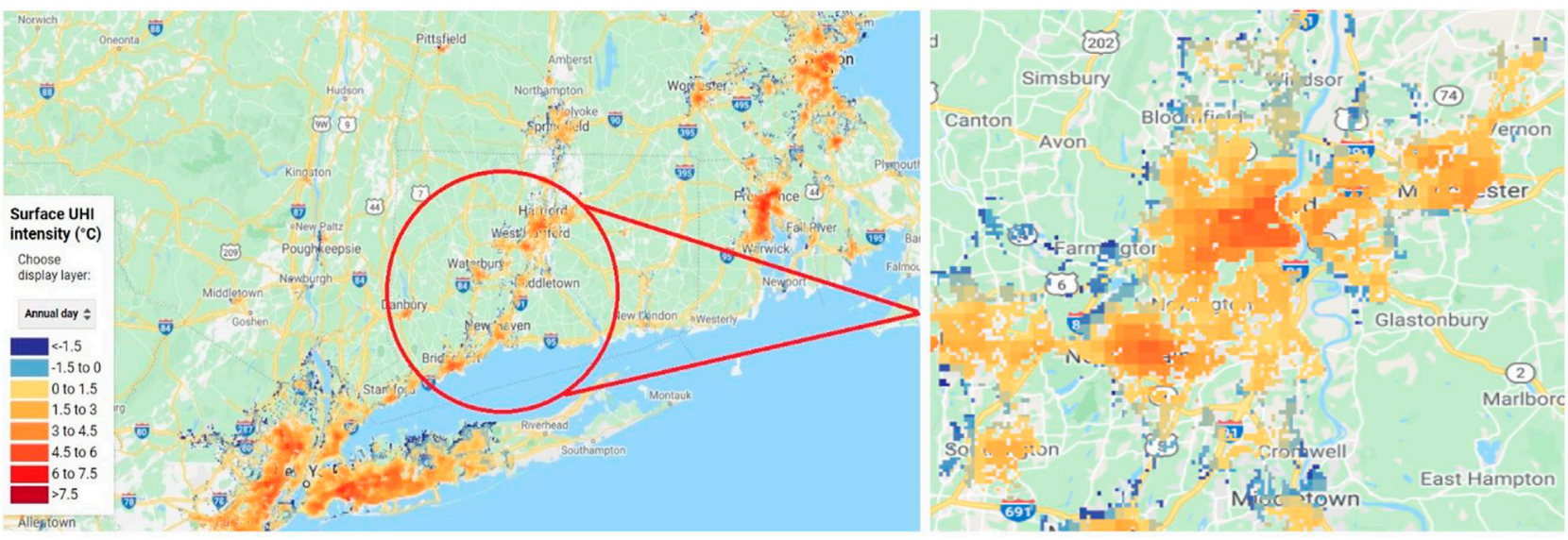

FIGURE 1 | Area satellite illustrations highlighting the impacts of UHI and surface temperatures in the United States (A) and Hartford region, Connecticut (A). (B) Adapted from Climate Central, 2014.

sub-urban areas due to additional built-up areas, abrupt changes to land use, development of infrastructures that reduce air quality, etc. (Kenward et al., 2014; EPA, 2021). Therefore, UHI has impacted occupants' comfort and their well-being in several cities and urban areas in many locations (EPA, 2001; Chakraborty and Lee, 2019), including different metropolises in the study area and across the United States as shown in Figure 1. The study (Kenward et al., 2014) recommends that planning and design of urban areas that integrate additional trees and parks, reflective roofs, and supplementary materials for urban infrastructure can help mitigate the impacts of UHIs. However, increasing greenhouse gas emissions are predicted to drive mean US summertime temperatures even higher in the next decades, aggravating UHIs and their related health risks (Kenward et al., 2014).

\subsection{COVID-19, Climate Change, and Urban Resilience}

Plough et al. (2013) explained the significance of building communities including cities' resilience to disasters. The authors (Plough et al., 2013) mentioned that communities that are created to be resilient to disasters should be able to mitigate and bounce back rapidly in the occurrences of public health emergencies including pandemics such as COVID-19, natural disasters, or any other threats. Chandra et al. (2010) stated that the core components of developing resilience to emergencies should include how to advance well-being, access, education, engagement, self-dependency, partnership, quality, and efficiency.

Furthermore, a report by the United Nations Office for Disaster Risk Reduction (UNISDR, 2012) highlighted main essentials to make cities more resilient. Some of the essentials include multi-hazard risk assessment, infrastructure protection, education and health, building regulations and land use planning, environmental protection and strengthening of ecosystems, early warning and response, recovery and rebuilding, and others. These essentials and framework developed for each variable are crucial steps taken to address and reduce risks relating to health, growth, and climate change (Aitsi-Selmi et al., 2015).

Cheshmehzangi (2020) mentioned the issues relating to preparedness through urban resilience. The study explained how cities should be boosted and planned for emergencies. Existing research also examined different forms of resilience that cities should prepare. These forms of resilience include disaster (Manyena, 2006; Bosher, 2014), engineering (Klein et al., 2003; Davoudi et al., 2012; Eken, 2019), ecological (Monstadt, 2009; Davoudi et al., 2012), socio-ecological (Meerow and Newell, 2016; Eken, 2019), evolutionary (Davoudi et al., 2012), built-in (Bosher, 2014), and climate change (Adger et al., 2011).

According to the Intergovernmental Panel on Climate Change (IPCC, 2019), climate change has a substantial impact on numerous communities across the globe. The report noted that the effects are more intensely felt in most populated communities and cities. Climate change has also been associated with a rise in the frequency of natural disasters in various locations (Yilmaz, 2021). Additionally, a range of interventions has been developed under various topics such as sustainable cities, climate-friendly initiatives, and low-carbon metropolises (Yilmaz, 2021). Existing research has also discussed that cities are usually warmer than rural districts and this outcome can be attributed to the effect referred to as urban heat island-UHI (Ward et al., 2016). Therefore, the UHI phenomenon can result in different forms of discomfort such as thermal, mental, health, etc. for people in such thermal conditions (Luber and McGeehin, 2008). Thermal topology is evaluated as one of the initiatives that can help minimize discomfort in different thermal spaces (Saraoui et al., 2018).

On the relationship between the pandemic (COVID-19) and climate change, a study assessed the effects of the pandemic on the performance of the thermal environment (Alonso et al., 2021). The study (Alonso et al., 2021) noted that carbon dioxide $\left(\mathrm{CO}_{2}\right)$ levels decreased by $400 \mathrm{ppm}$ per week when natural ventilation is considered during the operating hours. 

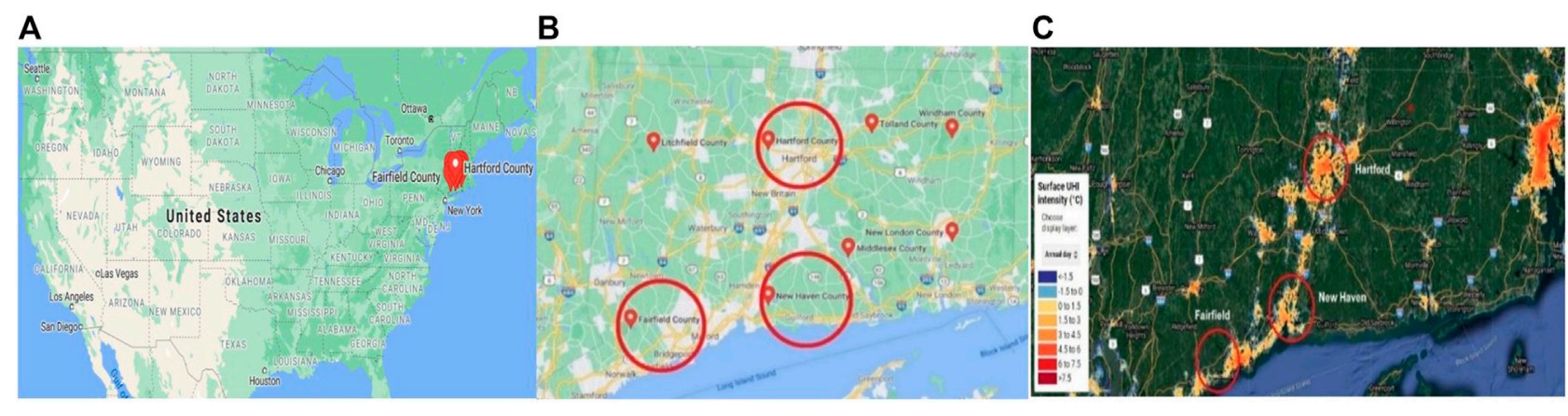

FIGURE 2 | Map of the United States showing the locations of the counties within the state of Connecticut (A), close map of the study area highlighting the locations of the three counties (B) and impacts of urban heat islands amplified by climate change within the study area (C).

TABLE 1 | Summary of the main features of the selected counties ${ }^{a}$

\begin{tabular}{|c|c|c|c|}
\hline Features/County & Fairfield & Hartford & New Haven \\
\hline Largest city & Bridgeport & Hartford & New Haven \\
\hline Coordinates & $41.2560^{\circ} \mathrm{N}, 73.3709^{\circ} \mathrm{W}$ & $41.7924^{\circ} \mathrm{N}, 72.8043^{\circ} \mathrm{W}$ & $41.3267^{\circ} \mathrm{N}, 72.8043^{\circ} \mathrm{W}$ \\
\hline Total area $\left(\mathrm{km}^{2}\right)$ & $2,167.82$ & 1942.49 & $2,232.57$ \\
\hline Land area $\left(\mathrm{km}^{2}\right)$ & $1,618.74$ & 1903.90 & $1,565.67$ \\
\hline Population estimates & 943,332 & 891,720 & 854,757 \\
\hline Population per km² & $3,800.03$ & $3,149.94$ & $3,695.14$ \\
\hline No of towns and cities & 32 & 48 & 28 \\
\hline Major economic activities & $\begin{array}{l}\text { Wholesales, shipments, accommodation, food } \\
\text { services }\end{array}$ & $\begin{array}{l}\text { Wholesales, retails, shipment, finance, } \\
\text { insurance }\end{array}$ & $\begin{array}{l}\text { Wholesales, shipments, retails, } \\
\text { healthcare }\end{array}$ \\
\hline $\begin{array}{l}\text { Average household } \\
\text { income }\end{array}$ & $\$ 95,645$ & $\$ 75,148$ & $\$ 69,905$ \\
\hline Housing units & 375,360 & 381,401 & 368,670 \\
\hline
\end{tabular}

aSome data are extracted from the US, Census Bureau, 2021, QuickFacts.

Despite this encouraging outcome, thermal discomfort was still reported during those hours due to concerns about the environmental quality of the thermal environment. Moreover, the Occupational Safety and Health Administration (OSHA, 2020) provided the COVID-19 guidance on the use of cloth face covering for people working or staying outdoors in hot and humid weather conditions. The report (OSHA, 2020) noted that people in such an environment may find using face covering uncomfortable outdoors. However, people without masks in areas that are prone to poor environmental quality including pollution, odour, etc., may also be prone to various risks.

To address the effect of climate change on our society, different policies have been formulated to lessen the impact across various regions of the world. According to the United Nations Framework Convention on Climate Change (UNFCCC), nearly every nation including the United States has agreed to reduce greenhouse gas (GHG) emissions to a level that will not lead to dangerous anthropogenic (human-induced) interruption with the climate system (United Nations (UN), 1992). The Intergovernmental Panel on Climate Change (IPCC) released a report on Global Warming of $1.5^{\circ} \mathrm{C}$ in 2018. The report outlined the effects of a $1.5^{\circ} \mathrm{C}$ temperature increase and recommends mitigation approaches to remain below the $1.5^{\circ} \mathrm{C}$ mark (Intergovernmental Panel on Climate Change (IPCC), 2018). EPA (2001) recommends market-based instruments and regulatory instruments as part of the general policies for mitigating the impact of climate change. For instance, in the US, the Safer Affordable Fuel-Efficient (SAFE) vehicles rule was put into effect in 2020 (NHTSA (National Highway Traffic Safety Administration) and EPA, 2020). The rule was administered by National Highway Traffic Safety Administration (NHTSA). The directive provides lower efficiency improvement marks of $1.5 \%$ per annum than the 2012 Corporate Average Fuel Economy (CAFE) benchmarks (Federal Register, 2012; NHTSA (National Highway Traffic Safety Administration) and EPA, 2020). These

TABLE 2 | Summary of the historical climatic data of averages up to 50-years record in the counties.

\begin{tabular}{lccc} 
Variables/County & Fairfield $^{\mathbf{a}}$ & Hartford & New Haven \\
\hline Average temp. $\left({ }^{\circ} \mathrm{C}\right)$ & 11.4 & 10.1 & 12.0 \\
Average max. temp. $\left({ }^{\circ} \mathrm{C}\right)$ & 15.7 & 15.7 & 16.9 \\
Average min. temp. $\left({ }^{\circ} \mathrm{C}\right)$ & 7.1 & 4.3 & 7.3 \\
Average no of days $>32^{\circ} \mathrm{C}$ & 6.3 & 17.8 & 18.6 \\
Average no of days $<0^{\circ} \mathrm{C}$ & 92.1 & 132.6 & 85.9 \\
Average precipitation $(\mathrm{mm})$ & $1,084.6$ & $1,149.0$ & $1,216.0$ \\
Average $\mathrm{RH}(\%)$ & 67.6 & 66.7 & 72.0 \\
Average wind speed $(\mathrm{km} / \mathrm{h})$ & 16.9 & 12.6 & 13.0 \\
Average snowfall $(\mathrm{cm})$ & 70.1 & 123.4 & 15.8 \\
Average dew-point $\left({ }^{\circ} \mathrm{C}\right)$ & 5.3 & 3.7 & 5.0
\end{tabular}

${ }^{a}$ Historical data for the city of Bridgeport in Fairfield County. 
policies are part of the initiatives that can help in attaining zerocarbon cities.

\subsection{Outdoor Comfort and Thermal Indices}

In terms of the assessments of outdoor comfort and thermal indices in cities to make them resilient, Lau et al. (2019) mentioned outdoor comfort is influenced by urban morphology and the forms of the urban environment. Bajšanski et al., 2015 examined different variables to improve outdoor comfort in municipalities during extreme weather conditions by exploring automatic algorithms. The study (Bajšanski et al., 2015) found out that an increase in the thermal indices (such as the Universal Thermal Climate Index-UTCI) leads to a decrease in the building height and population density within the metropolis. Additionally, the shading from the buildings also reduces the possibility of thermal stress in summer and vice-versa in winter.

On the possible impact and interrelation between the COVID19 pandemic, occupants' comfort, and thermal indices, Aram et al. (2020) noted that in more populated metropolises, an increase in air temperature because of urban heat island (UHI) can affect thermal comfort and health of the people. Populated urban areas and low-income neighborhoods in inner cities, especially in the US are disproportionately affected by the pandemic due to various factors such as poor indoor environmental quality, limited open and green areas, energy poverty, health-related issues, etc. (Gout and Kelly, 2020; Environmental Health, 2021). The investigations (Gout and Kelly, 2020; Environmental Health, 2021) noted that the pandemic amplifies racial and socio-economic disparities regarding comfort and vulnerability of people to extreme weather conditions in different seasons.

Existing research explained that large parks in urban areas can improve thermal comfort of people and the impact of UHI (Ward et al., 2016; Aram et al., 2020), especially during the warm seasons when changes in temperatures are more noticeable than other seasons Aram et al., 2020). Therefore, this study intends to examine if there are noticeable differences regarding the impact of the pandemic on occupants' comfort and thermal indices before and during the period in various urban areas.

Several investigations on thermal comfort have been widely considered due to the noticeable effect of thermal comfort on the quality of life of people (Chen and $\mathrm{Ng}, 2012$ ). Past research noted that on the one hand, human comfort is influenced by various parameters such as humidity, air movements, solar radiation, climate, sunlight, air temperature (Nikolopoulou and Lykoudis, 2006; Rupp et al., 2015). On the other hand, occupants' perception of the thermal environment is affected by nonclimatic variables like age, clothing layer, age, etc. (Djongyang et al., 2010). The literature reveals various variables that can influence occupants' comfort and their perceptions in various thermal spaces.

To date, different thermal indices have been developed (Gagge et al., 1986; Jendritzky et al., 2009), and applied to assess thermal comfort of people in various thermal environments (Aram et al., 2020; Adekunle, 2021). Some of the thermal indices developed for evaluating outdoor thermal comfort include Standard Effective
Temperature-SET (Gagge et al., 1986), Wet Bulb Globe Temperature-WBGT, Universal Thermal Climate Index-UTCI (Jendritzky et al., 2009), Physiological Equivalent Temperature-PET (Höppe, 1999), Predicted Mean Vote-PMV (Fanger, 1973), and others. Also, Potchter et al. (2018) and Aram et al. (2020) mentioned thermal indices such as SET, UTCI, PMV, and PET as the four widely used indices in investigations on outdoor thermal comfort. The extensive literature review and mathematical models on these thermal indices have been considered in existing research (Aram et al., 2020; Adekunle, 2020; Adekunle, 2021), and they will not be discussed in this paper. In the current study, the thermal indices will also be explored to assess outdoor thermal comfort in the study location.

\section{METHODS}

The research approaches explored in this study followed the outlines presented below.

1) Development and design of the research including the research aim, questions, and objectives.

2) Review of the literature to capture the research gaps this study intends to fill.

3) Assessments of the study areas to ensure the criteria (location of the counties within Connecticut, populations, etc.) set for the selected locations are met.

4) Measurements and collection of environmental variables.

5) Analysis and interpretation of the research data.

6) Findings and discussion on the main results obtained from the study. The study also discussed the research limitations.

7) Conclusion, recommendations, and possible areas for future research.

The study expects that future research can expand on all or some of the research approaches outlined in this research.

\subsection{Study Area}

The research considered the most populated counties in Connecticut $\left(41.6032^{\circ} \mathrm{N}, 73.0877^{\circ} \mathrm{W}\right)$ in the Northeast of the US. According to Köppen-Geiger climate classification and Köppen climatic chart (Kottek et al., 2006), the climate of the study area varies from humid continental one (Dfa, Dfb) in the northern part of the state to humid subtropical (Cfa, Cfb) in the south. Generally, summertime in the study location is hot and humid. In wintertime, the weather conditions can vary from mild in the coastal areas to cold and snow in the other parts of the state. The counties examined in this study include Fairfield, Hartford, and New Haven (Figure 2). The three counties account for more than $75 \%$ of the state's population. The selected counties remain the economic hubs of the state and attract diverse populations who either live or work in the areas which may be impacted by the pandemic. Due to the populations and demographics of the selected counties, especially in urban and low-income areas, people may be subject to health, heat, and cold stress-related problems. The counties are selected as the sites for this study due to their impacts of urban heat islands, high populations, urban 


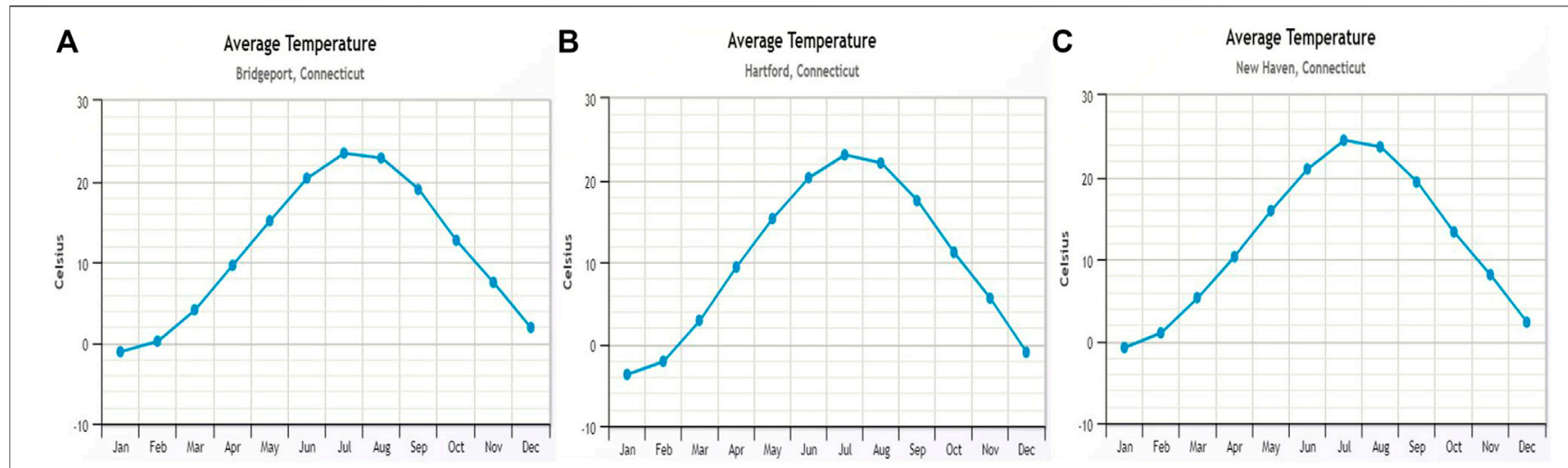

FIGURE 3 | Historical data showing average outdoor temperatures (monthly) in the counties [Fairfield (Bridgeport) - (A), Hartford-(B), and New Haven-(C)].
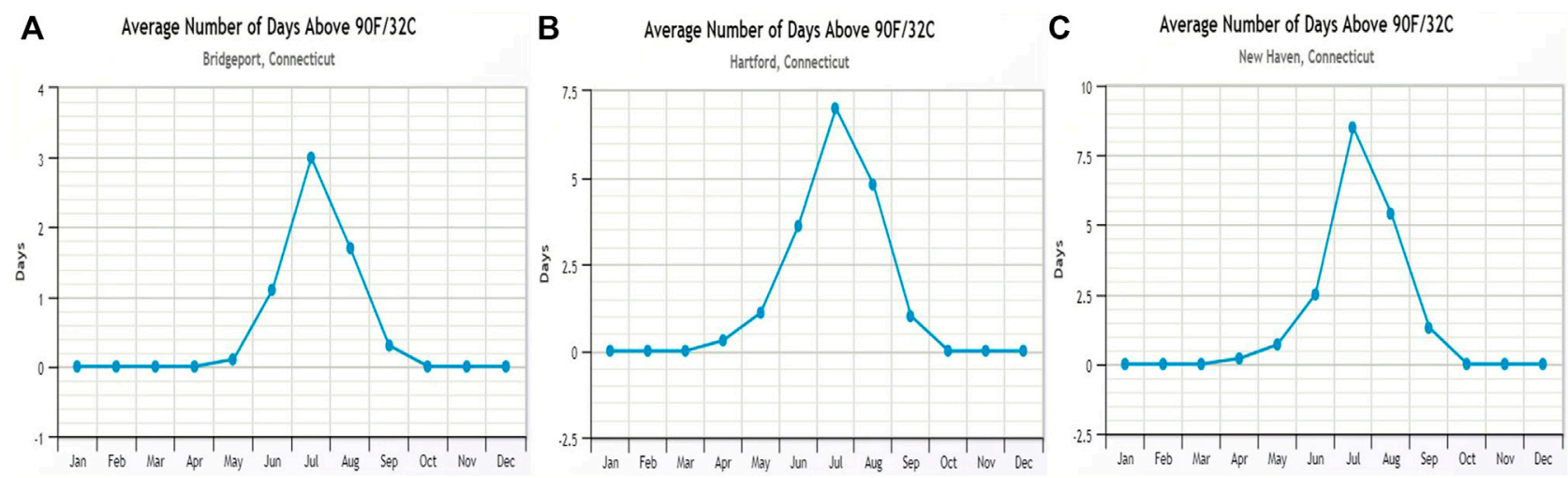

FIGURE 4 | Historical data showing the average number of days above $32^{\circ} \mathrm{C}$ (monthly) in the counties [Fairfield (Bridgeport) - (A), Hartford - (B), and New Haven-(C)].

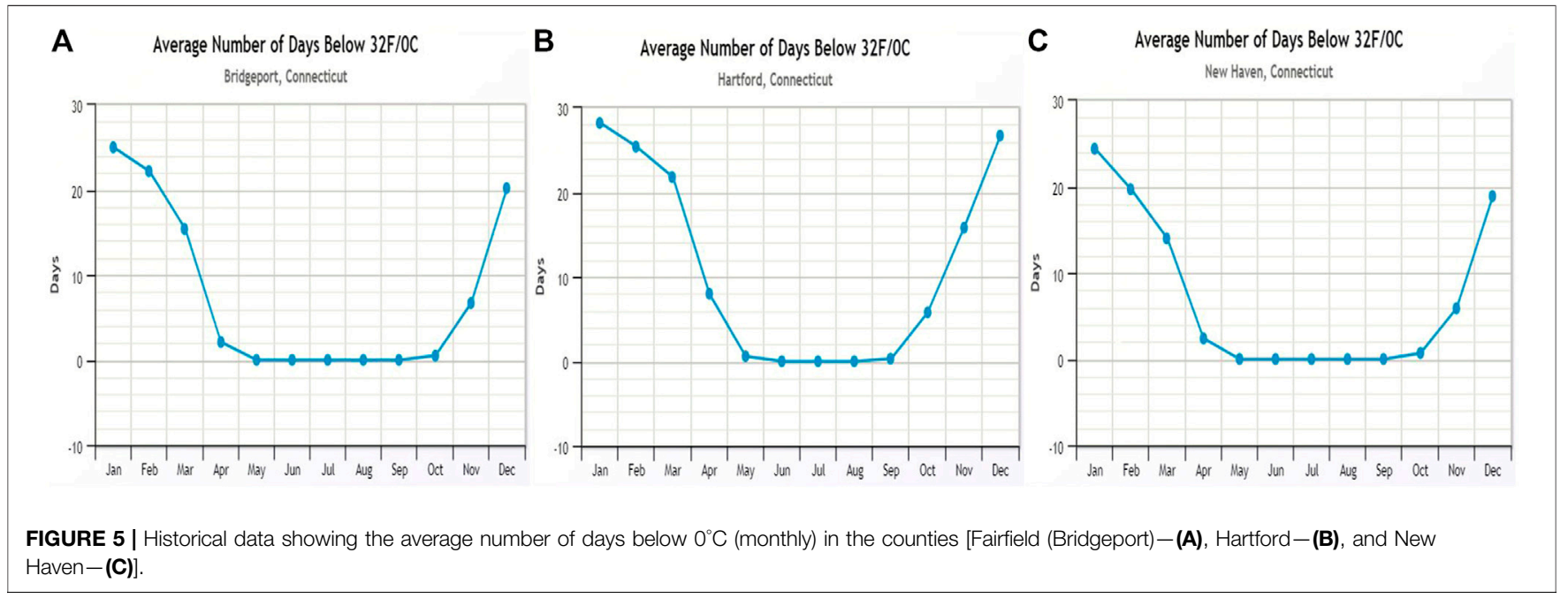

built-up, economic activities, and strategic locations to other major cities within the region. For instance, Fairfield and New Haven counties are within a 2-h drive to the city of New York.
Likewise, Hartford is within a 2-h drive to the city of Boston in Massachusetts. Table 1 summarises the main features of the selected counties. 


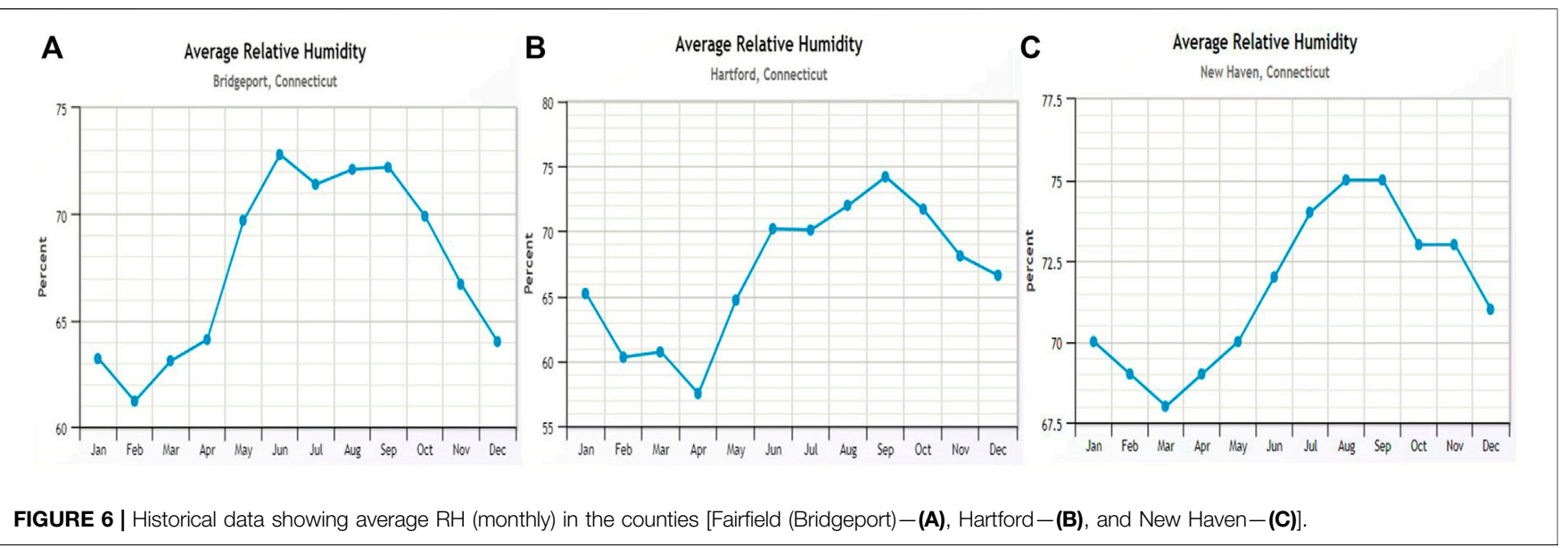

In terms of the land area and the number of towns and cities in each of the counties, Hartford is the largest county. Concerning the total geographical area of the study area (land and water), New Haven is the largest county; while Fairfield is the most populated and richest county when it comes to the population estimates and average income per household. Table 2 below summarises the historical data of the study area. Also, Figures 3-6, Supplementary Figures S7, S8 present the charts of historical climatic data obtained from the study areas.

\subsection{Measurements of Microclimate}

The research considered the collection of measured environmental variables at 60-min intervals for a year before (January to December 2019) and during the pandemic (January to December 2020). The variables include air temperature, relative humidity (RH), dew-point, precipitation, solar irradiation, wind speed, gust, sea level pressure, and others. The measured variables from the meteorological stations were considered based on their proximity to the major cities in each of the counties. The study also considered the weather stations that provide the required data that can be considered for analysis. For instance, the microclimate variables for Fairfield County were collected from a local meteorological station in Bridgeport. The weather station is within the city of Bridgeport, the largest metropolitan area in Fairfield County. In Hartford County, the weather data were gathered from a meteorological station at the International Airport within the county. The weather station is less than a 20-min drive to the downtown of the city of Harford, the largest city in the county. For New Haven County, the microclimate variables were collected from a nearby airport near the city of New Haven. The airport is within an $8 \mathrm{~km}$ radius of downtown, the city of New Haven.

The data are checked and loaded into statistical software (such as Microsoft Excel and SPSS-Statistical Package for the Social Sciences) for analysis and to find associations between the variables. Additionally, observations and mathematical models to compute the indices (such as the Wet Bulb Globe Temperature-WBGT and Universal Thermal Climate Index-UTCI) are considered. The mathematical models (e.g., UTCI) were developed by previous investigators (Jendritzky et al.,
2009). The features of the mathematical models, how they were developed and can be applied have been discussed in existing research (Adekunle, 2021). Therefore, the development of mathematical models will not be covered in this paper. By applying the mathematical models, the study assessed the range of the indices for determining people's vulnerability to heat or cold stress. The approach regarding the methodology adopted in this current has been explored in similar existing research (Aram et al., 2020). However, the current study explored more indices and captured a wide range of data over an extended period than some of the similar investigations in the field.

TABLE 3 | Summary of the averages of the environmental variables and thermal indices in the study locations.

\begin{tabular}{lccc} 
Variables/County & Fairfield & Hartford & New Haven \\
\hline 2019 & & & \\
Average temp. $\left({ }^{\circ} \mathrm{C}\right)$ & 15.0 & 10.7 & 12.1 \\
Average max. temp. $\left({ }^{\circ} \mathrm{C}\right)$ & 10.0 & 15.9 & 16.3 \\
Average min. temp. $\left({ }^{\circ} \mathrm{C}\right)$ & 4.9 & 5.6 & 7.8 \\
Average dew-point $\left({ }^{\circ} \mathrm{C}\right)$ & 4.3 & 3.9 & 5.9 \\
Average precipitation $(\mathrm{mm})$ & 2.9 & 4.0 & 3.3 \\
Average RH (\%) & 70.7 & 62.8 & 65.8 \\
Average wind vel. $(\mathrm{km} / \mathrm{h})$ & 9.1 & 12.3 & 11.5 \\
Average sea level pressure & 999.6 & $1,010.1$ & $1,016.1$ \\
WBGT ( $\left.{ }^{\circ} \mathrm{C}\right)$ & 8.2 & 8.5 & 9.9 \\
UTCl ( $\mathrm{C}$ ) & 10.1 & 10.7 & 12.2 \\
2020 & & & \\
Average temp. $\left({ }^{\circ} \mathrm{C}\right)$ & 11.0 & 11.6 & 12.8 \\
Average max. temp. $\left({ }^{\circ} \mathrm{C}\right)$ & 16.1 & 17.1 & 17.0 \\
Average min. temp. $\left({ }^{\circ} \mathrm{C}\right)$ & 5.8 & 6.3 & 8.4 \\
Average dew-point $\left({ }^{\circ} \mathrm{C}\right)$ & 5.4 & 4.6 & 7.2 \\
Average precipitation $(\mathrm{mm})$ & 2.9 & 3.0 & 2.5 \\
Average RH (\%) & 68.4 & 62.6 & 68.8 \\
Average wind vel. $(\mathrm{km} / \mathrm{h})$ & 9.4 & 12.7 & 11.5 \\
Average sea level pressure & 995.4 & $1,010.4$ & $1,016.2$ \\
WBGT ( $\left.{ }^{\circ} \mathrm{C}\right)$ & 9.2 & 9.3 & 10.9 \\
UTCl $\left({ }^{\circ} \mathrm{C}\right)$ & 11.2 & 11.6 & 13.0
\end{tabular}


TABLE 4 | Summary of the averages of the direct normal irradiation, global horizontal irradiation, diffuse horizontal irradiation, and other parameters.

\begin{tabular}{|c|c|c|c|}
\hline Variables/County & Fairfield & Hartford & New Haven \\
\hline Mean direct normal irradiation $\left(\mathrm{kWh} / \mathrm{m}^{2}\right)$-yearly sum & $1,585.8$ & $1,543.9$ & $1,590.5$ \\
\hline Mean hourly direct normal irradiation $\left(\mathrm{kWh} / \mathrm{m}^{2}\right)$ from $07: 00-17: 00$ & 403.1 & 391.4 & 403.6 \\
\hline Mean hourly direct normal irradiation $\left(\mathrm{kWh} / \mathrm{m}^{2}\right)$ from 10:00-14:00 & 472.0 & 455.3 & 471.4 \\
\hline Mean global horizontal irradiation $\left(\mathrm{kWh} / \mathrm{m}^{2}\right)$-yearly sum & 1,485 & $1,447.1$ & $1,481.9$ \\
\hline Diffuse horizontal irradiation $\left(\mathrm{kWh} / \mathrm{m}^{2}\right)$ & 585.7 & 584.3 & 583.8 \\
\hline Global tilted irradiation at optimum angle $\left(\mathrm{kWh} / \mathrm{m}^{2}\right)$ & $1,753.5$ & $1,718.8$ & $1,751.8$ \\
\hline Terrain elevation (m) & 5.0 & 24.0 & 10.0 \\
\hline
\end{tabular}

TABLE 5 | Summary of the mean annual temperatures and direct normal irradiation in the locations.

\begin{tabular}{|c|c|c|c|c|c|c|}
\hline County & Fairfield-historical & Fairfield-2020 & Hartford-historical & Hartford-2020 & $\begin{array}{c}\text { New } \\
\text { Haven-historical }\end{array}$ & $\begin{array}{c}\text { New } \\
\text { Haven-2020 }\end{array}$ \\
\hline Average temp. $\left({ }^{\circ} \mathrm{C}\right)$ & 11.4 & 11.0 & 10.1 & 11.6 & 12.0 & 12.8 \\
\hline $\begin{array}{l}\text { Average direct normal irradiation } \\
\left(\mathrm{kWh} / \mathrm{m}^{2}\right)\end{array}$ & 133.8 & 183.3 & 130.1 & 178.2 & 133.9 & 183.4 \\
\hline $\begin{array}{l}\text { Yearly (sum) direct normal } \\
\text { irradiation }\left(\mathrm{kWh} / \mathrm{m}^{2}\right)\end{array}$ & $1,605.2$ & $2,199.1$ & $1,561.1$ & $2,138.9$ & $1,606.4$ & $2,200.6$ \\
\hline
\end{tabular}

radiation $\left(\mathrm{kWh} / \mathrm{m}^{2}\right)$

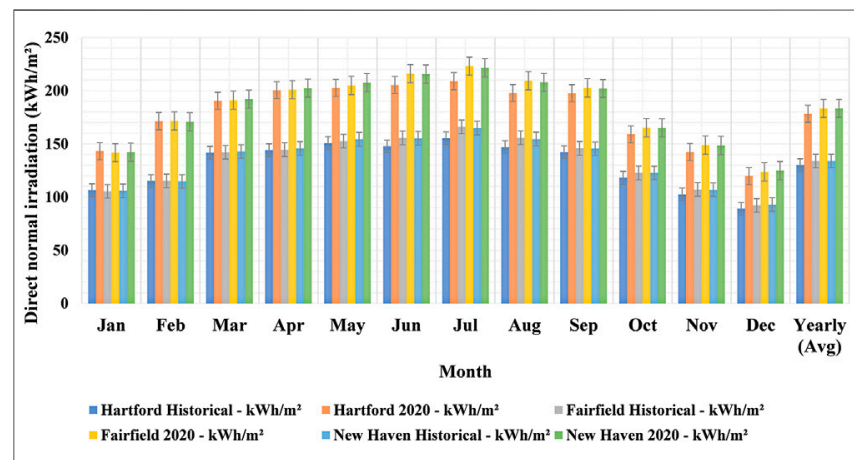

FIGURE 7 | Comparison of the mean monthly and annual direct normal irradiation values (historical and 2020) in Fairfield, Hartford, and New Haven.

\section{DATA ANALYSIS}

The historical data of the selected counties showed that over the last 5 decades (Tables 3, 4), the highest minimum, maximum, and average temperatures were reported in New Haven County. The data analysis revealed that the effects of UHI are likely to be more noticeable in New Haven than other counties due to the built environment over a lesser area of land than other counties. Moreover, New Haven has the lowest mean annual income per household among the three counties considered in this study. From the literature, it is noted that populated and low-income areas are more affected by the impact of the pandemic coupled with climate change. The data showed this may have influenced occupants' comfort in metropolises within the county (New Haven) more than other counties over the last few decades.

The data analysis revealed the mean annual temperatures and $\mathrm{RH}$ before the pandemic (i.e., 2019) ranged from $10.7^{\circ} \mathrm{C}$ to $15.0^{\circ} \mathrm{C}$, and $62.8-70.7 \%$. During the pandemic (2020), the mean temperatures varied from $11.0^{\circ} \mathrm{C}$ to $12.8^{\circ} \mathrm{C}$ while the average
RH ranged from 62.6 to $68.8 \%$. The analysis showed that higher mean annual temperatures were recorded in Hartford and New Haven counties during the pandemic than before the period and vice-versa in Fairfield County. Similarly, higher thermal indices were computed in all the counties during the pandemic than before the pandemic. The analysis also revealed that higher $\mathrm{RH}$ values were recorded in the pre-pandemic period in the study locations than during the pandemic period except in New Haven County. The summary of the averages of the variables recorded before and during the pandemic is presented in Table 3 below.

On solar irradiation, the analysis also showed that the higher mean annual direct normal irradiation values are reported in New Haven than those values reported in Fairfield and Hartford. However, higher values of the mean annual global horizontal irradiation, diffuse horizontal irradiation, etc. are observed in Fairfield than in Hartford and New Haven. The data provided additional information on the vulnerability of people in New Haven to thermal and cold stress in various seasons. Across the case studies, higher direct normal irradiation values are recorded daily between 07:00 and 17:00 than other hours per day. Additionally, the highest mean values of the variables were observed daily between $10: 00$ and $14: 00$ in the locations. Table 4 summarizes the information collected on the mean direct normal irradiation, global horizontal irradiation, etc. in the study locations.

\section{RESULTS AND DISCUSSION}

The results of the annual mean microclimate data as shown in Table 5 revealed that Fairfield County is much warmer before the pandemic than during the pandemic and vice-versa in Hartford and New Haven counties. The UHI phenomenon caused by climate change, and other parameters such as the proximity of Fairfield County to the city of New York with more people, higher 

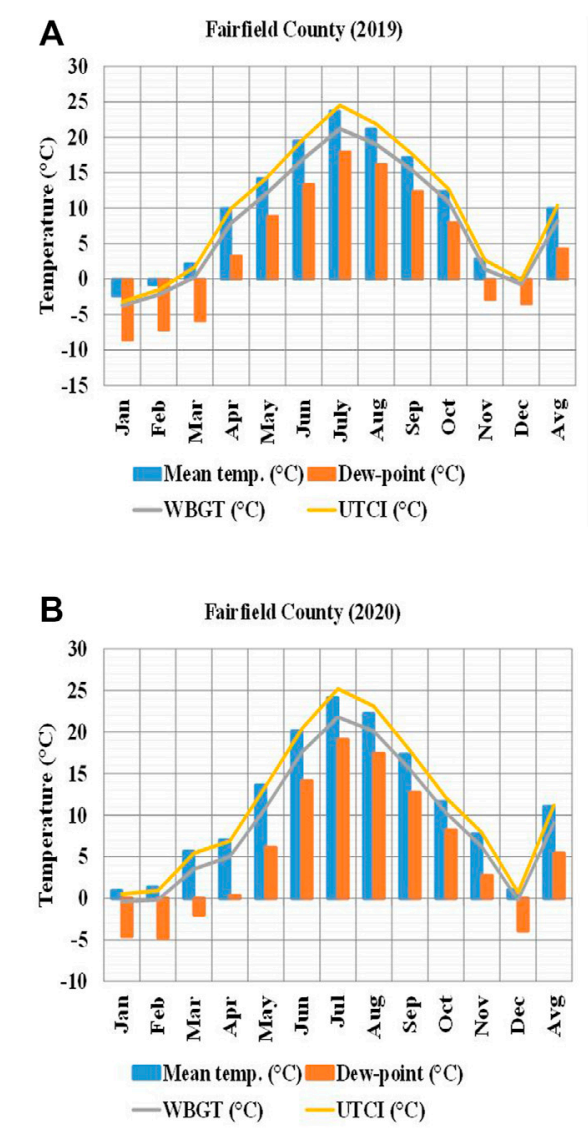
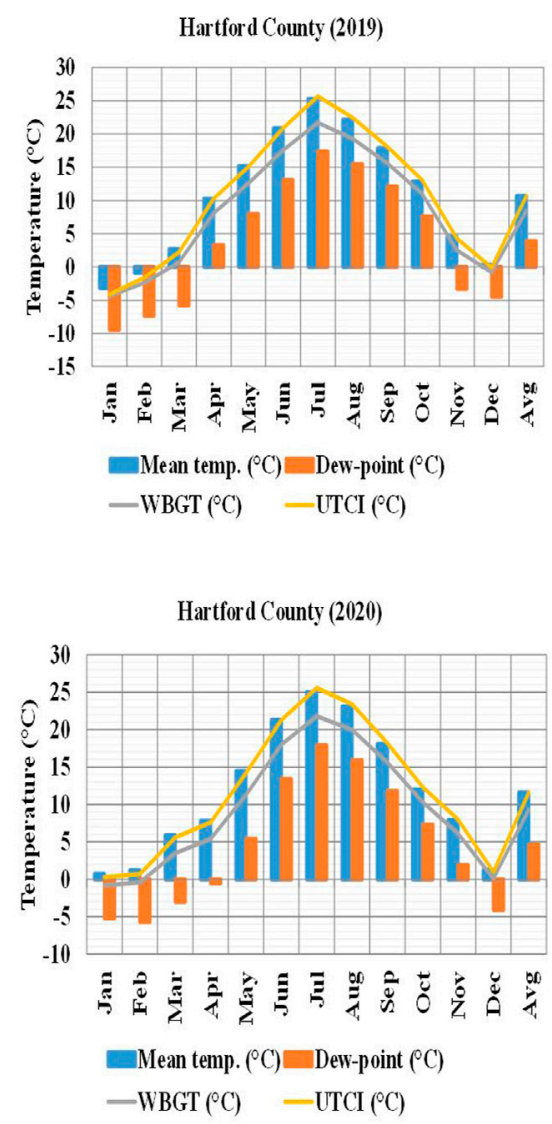
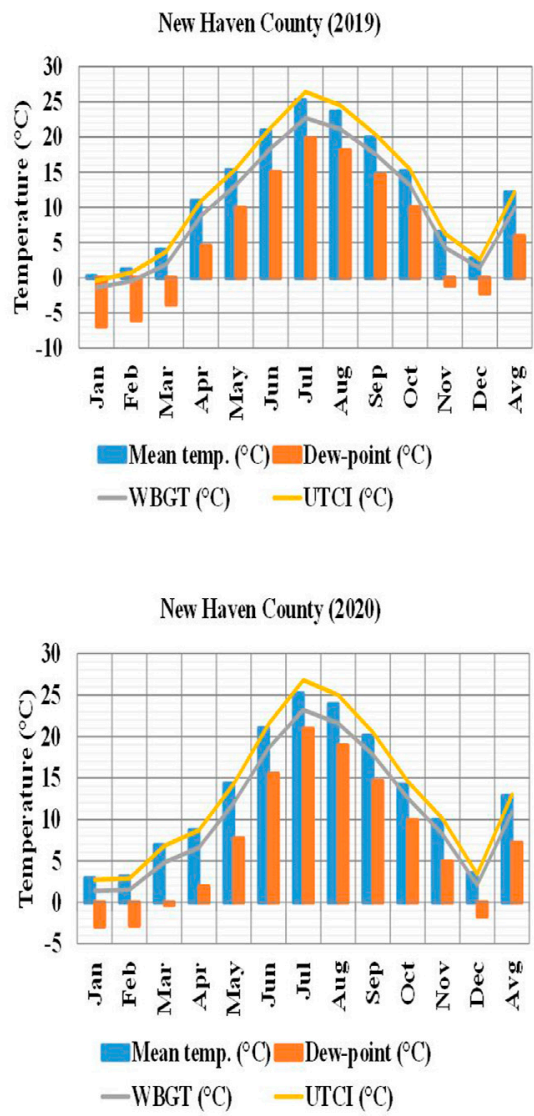

FIGURE 8 | (A): Links between mean temperatures, dewpoint, and thermal indices in Fairfield (left), Hartford (middle), and New Haven (right) in 2019 (prepandemic year). (B): Links between mean temperatures, dewpoint, and thermal indices in Fairfield (left), Hartford (middle), and New Haven (right) in 2020 (pandemic year).

population per square $\mathrm{km}$, increase in pollution rate, and higher carbon emissions from activities including frequent transport activities (cars, rails, etc.) may have contributed to the higher temperatures reported in Fairfield County before the pandemic than during the period. During the pandemic, the lockdown of activities has reduced all non-essential travels, activities, and led to less pollution and carbon emissions which could have contributed led to a drop of $4.0^{\circ} \mathrm{C}$ in annual mean temperature (Table 3). Also, a higher incidence of solar irradiation may have contributed to the higher temperatures recorded in the counties during the pandemic than in the prepandemic era (Table 5). Figure 7 illustrates the mean monthly and annual direct normal irradiation at the locations.

The study revealed that the pre-pandemic period was more humid in the counties than the pandemic period except in New Haven County. The county (New Haven) has the largest total area $\left(\mathrm{km}^{2}\right)$ but the lowest land area. New Haven County also has the largest area covered by water $\left(667 \mathrm{~km}^{2}\right)$, which is approximately $30 \%$ of the total area of the county. This development may contribute to the findings observed in the study location. Further analyses of the microclimate variables revealed that an increase in air speed tends to lower the temperature and reduces the impact of heat stress which can improve the outdoor comfort of occupants. The study noted that New Haven County has a higher population and dwellings per $\mathrm{km}^{2}$ in major cities and towns within the county than those in other counties, especially in Hartford County. The urban configuration and land area of New Haven County may also influence the humidity level of the study location.

Also, the average sea level pressure and precipitation were higher in 2019 (pre-pandemic year) than during the pandemic period (2020). The mean maximum, and minimum temperatures, as well as dewpoints, were higher in 2019 (prepandemic period) than in the pandemic era. Climate change, fewer activities by the residents also play a vital role in the changes observed regarding the sea level pressure, precipitation, air speed, thermal indices, and other parameters before and during the pandemic.

The research also found out that people are more vulnerable to thermal stress during the pandemic than before the period. During the cold seasons, people may be more vulnerable to cold stress before the pandemic than during the period. However, further assessments would be required to assess the level of vulnerability of people to the thermal environment. The 

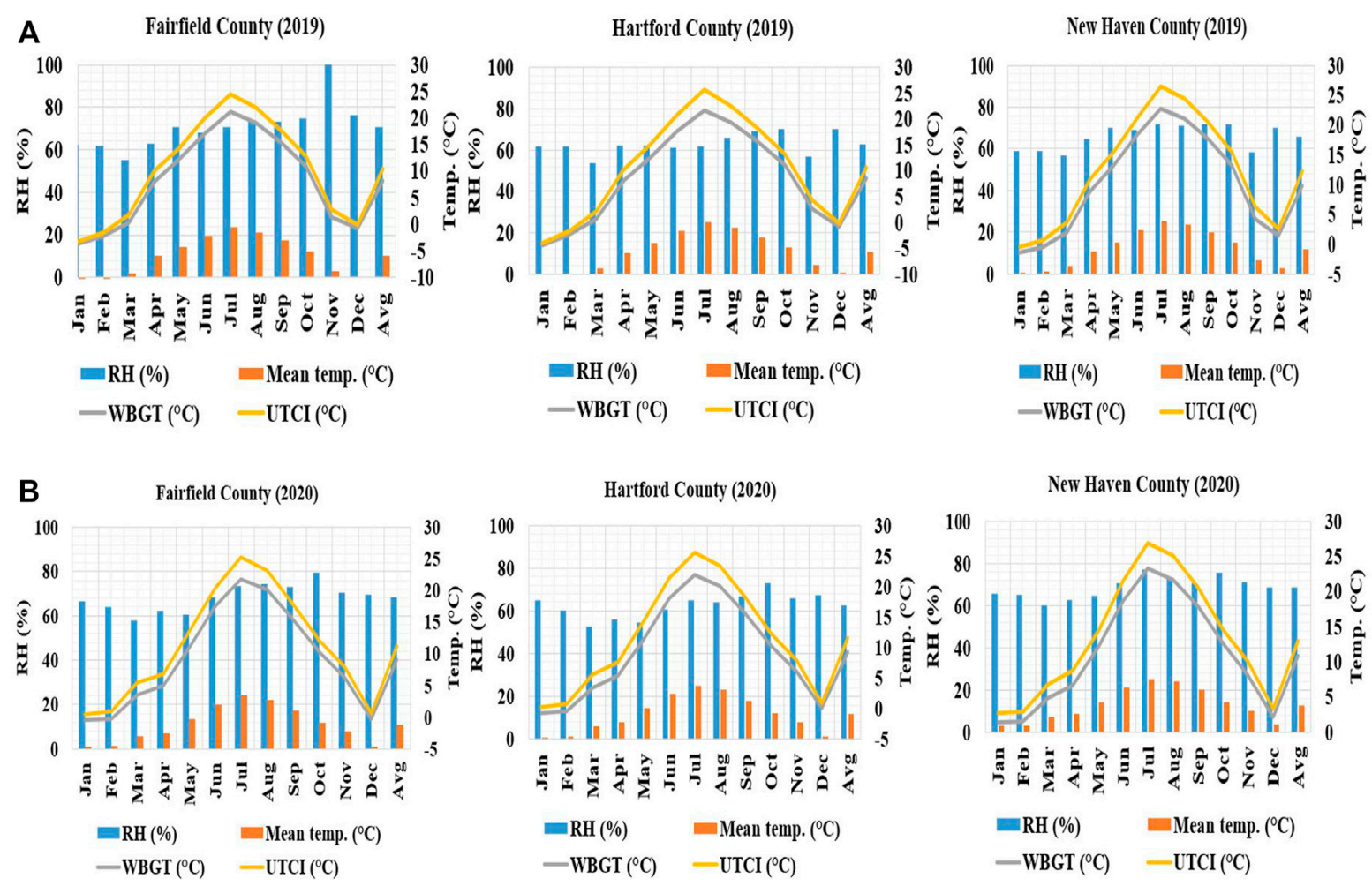

FIGURE 9 | (A): Links between mean RH, temperatures, and thermal indices in Fairfield (left), Hartford (middle), and New Haven (right) in 2019 (pre-pandemic year). (B): Links between mean RH, temperatures, and thermal indices in Fairfield (left), Hartford (middle), and New Haven (right) in 2020 (pandemic year).

results showed the impact of climate change and human activities on thermal comfort and well-being of people. Concerning the average monthly microclimate data, higher mean values were noted in the counties during July before (2019) and during the pandemic (2020). Temperatures and dewpoint tend to have a significant impact on the thermal indices in the study locations, especially during the warmer months than the rest of the year (Figures 8A,B). The research revealed that relationships exist between mean temperatures, dewpoint, and thermal indices before and during the pandemic, especially during the pandemic.

The results showed associations are found between mean RH, temperatures, and thermal indices in the study locations before and during the pandemic year. The study showed a rise in temperature and dewpoint also leads to an increase in thermal indices. An increase in $\mathrm{RH}$ does not lead to a significant increase in thermal indices, especially WBGT. The research revealed lower thermal indices in the cold months and $\mathrm{RH}$ has a less significant impact on thermal indices (Figures 9A,B). The research also showed that the thermal indices are strongly influenced by measured parameters such as mean outdoor temperatures (Figures 10A,B). Regression analyses showed the $R^{2}$ values to establish correlations between the variables varied from 0.9978 to 0.9998. Additionally, a combination of environmental variables such as temperatures, dew-point, gust, wind speed (Figures 11A,B), and others have significant effects on the indices.

The study also highlighted that across the counties, people are more vulnerable to thermal stress in summer than in any other season, especially during the pandemic year (Table 6). Since there is less pollution from various sources (vehicles, rails, aviation, etc.), lockdown of economic activities, higher incidence of solar radiation, and fewer carbon emissions, the impact of climate change is more felt during the pandemic, especially in warm seasons than the cold seasons. Additionally, higher population densities, urban forms, a rise in the number of towns and neighborhoods, and housing units, as well as lesser total areas observed in Fairfield and Hartford counties than in New Haven County, may also have contributed to the outcomes of this study.

The current study creates awareness regarding the impact of the pandemic occupants' comfort and their overall well-being in urban areas in the state of Connecticut. The study has also highlighted the need for developing rapid interventions for resilience in cities that are experiencing the UHI phenomenon amplified by climate change. Our cities including the study area should be developed to be more resilient to pandemics, thermal stress, disasters, health-related problems, etc., and safe for people across various spectra. The findings from the current study can also help in assessing and improving microclimatic conditions of the counties examined in this research. The study expects that populated urban and low-income areas would benefit from the study as experts and stakeholders seek opportunities and interventions to improve their thermal environment, especially by providing facilities, opportunities, and infrastructure that could improve the overall environmental quality of the study area. 

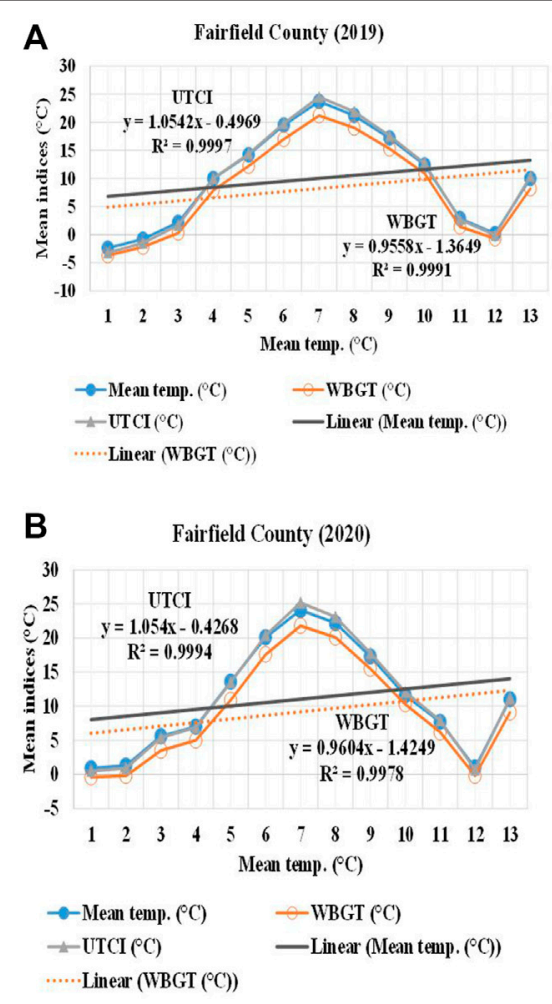
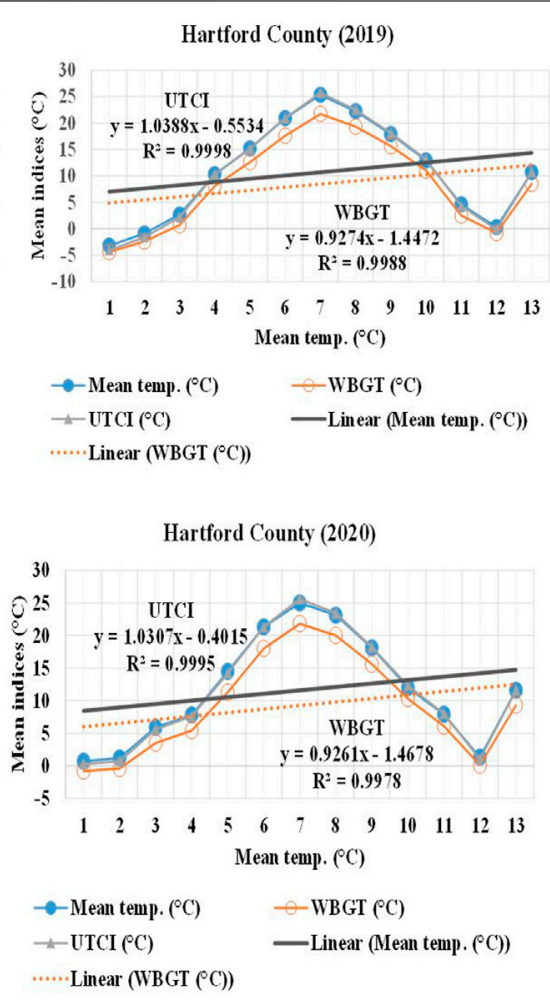
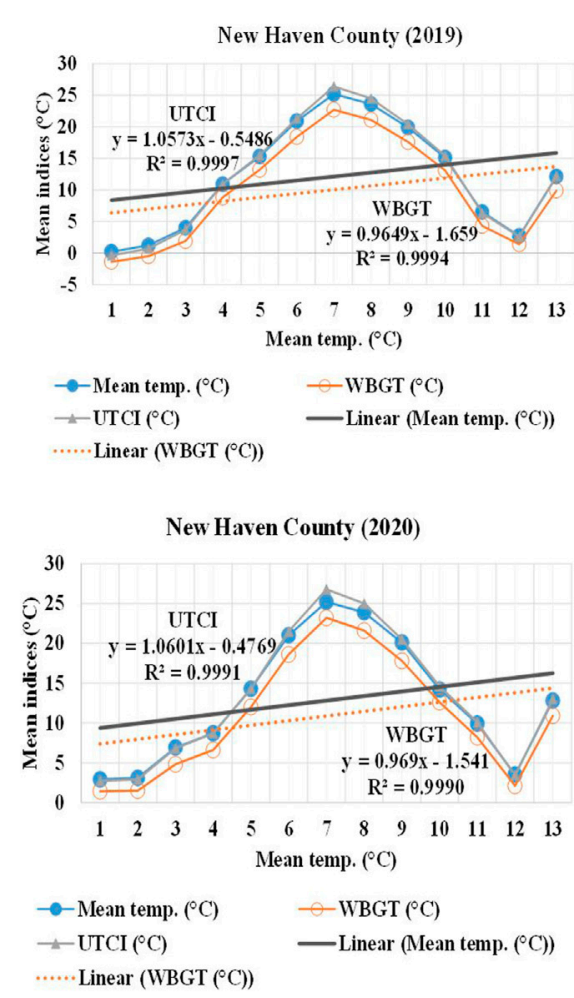

FIGURE 10 | (A): Correlations between mean temperatures and thermal indices in Fairfield (left), Hartford (middle), and New Haven (right) in 2019 (pre-pandemic year). (B): Correlations between mean temperatures and thermal indices in Fairfield (left), Hartford (middle), and New Haven (right) in 2020 (pandemic year).

Further research would consider the impact of additional microclimate variables before and during the pandemic in these locations. Future work will also consider additional thermal indices to assess outdoor comfort in the study locations. The current work provides the original contributions to the field being the first study to assess outdoor comfort and thermal indices before and during the pandemic in the study locations.

\section{CONCLUSION}

The study assessed the range of the indices for determining people's vulnerability to heat or cold stress. The investigation explored the collection of measured environmental parameters for a year (prepandemic) and 1 year during the pandemic from the nearby meteorological stations. The research also considered observations and mathematical models (such as the WBGT and UTCI). The findings showed the average monthly temperatures and $\mathrm{RH}$ varied from $-3.2^{\circ} \mathrm{C}$ to $25.2^{\circ} \mathrm{C}$ and $62.6-70.7 \%$, respectively. On the one hand, the thermal indices showed cold stress in wintertime, especially in Fairfield County. On the other hand, heat stress is reported in summertime across the counties. The highest mean minimum $\left(-7.8^{\circ} \mathrm{C}\right)$ and maximum $\left(31.9^{\circ} \mathrm{C}\right)$ temperatures are observed in Hartford County. New Haven County is more prone to heat stress than other counties because of some contributing factors (climate change, less pollution from activities, higher incidence from solar radiation, fewer land areas for vegetation, etc.). The outcomes revealed a broad range of thermal indices in different seasons. Higher thermal indices are calculated during the pandemic than those reported for the year before the pandemic which could have impacted the overall thermal comfort of people, health, and their well-being.

Based on the findings obtained from this investigation, the study suggests that efforts should be made by major stakeholders including government officials in developing and promoting local legislations as well as planning guidelines in the state of Connecticut surrounding the development of more sustainable landscapes for the inhabitants. With these initiatives, sustainable landscapes can help in reducing the impact of climate change on residents and their well-being in urban areas. The research recommends that additional interventions should be considered for developing resilience to emergencies in urban areas. Some of the interventions (such as policies that encourage the use of vehicles with clean energy) should be considered.

Adoption of clean energy initiatives would improve the environmental quality of the locations. The use of clean energy could serve as a reliable indicator to quantify and provide some background information on how the UHI landscape has changed in the study locations. For instance, assessments of the greenhouse gas emissions (such as $\mathrm{CO}_{2}$ ), air quality, pollution rate, solar irradiation, visibility rate, etc., before and after the intervention (clean energy) could provide useful information on how the UHI landscape has changed over the time. Various forms of incentives should be made 


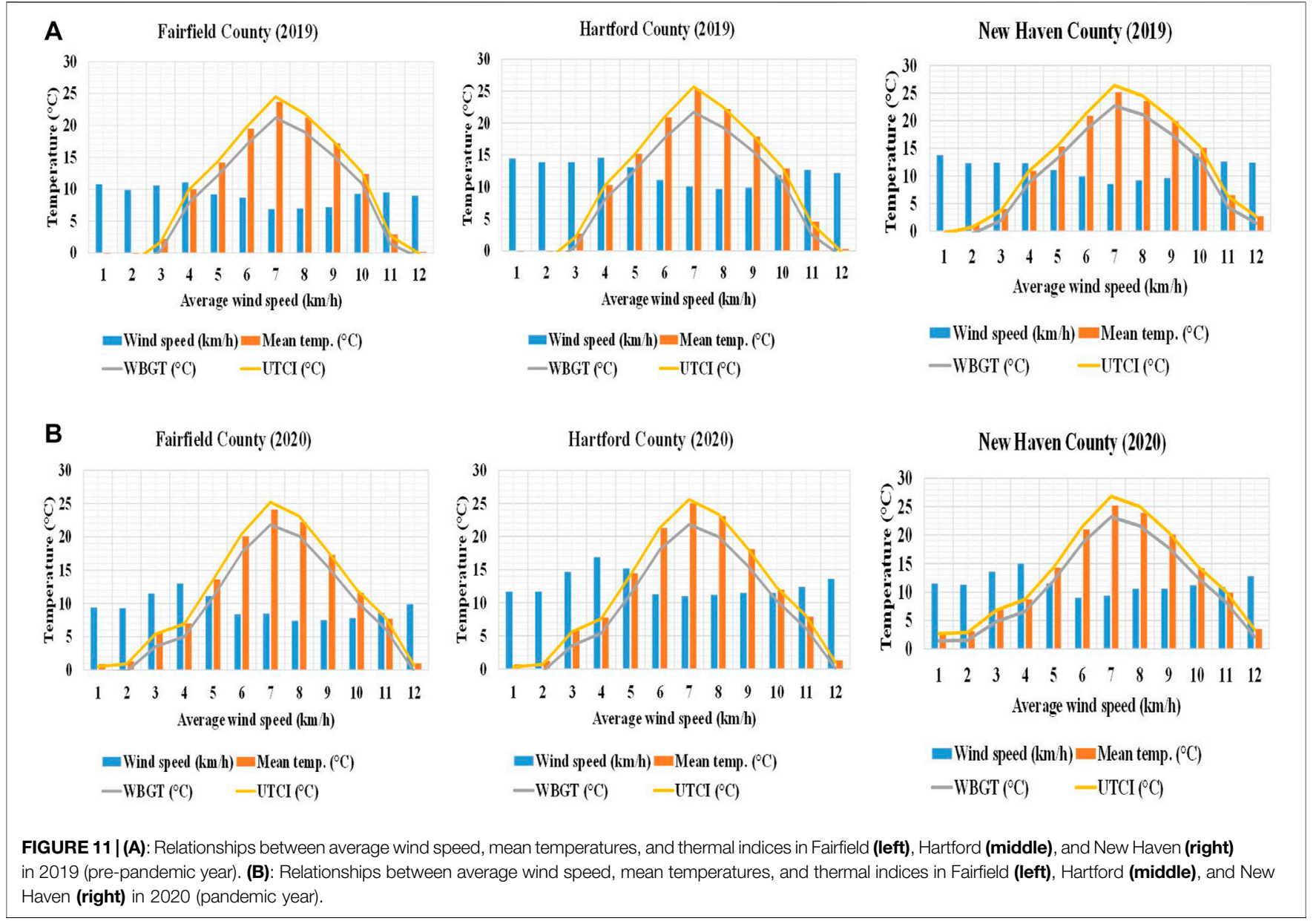

TABLE 6 | Summary of the seasonal averages of the environmental variables in the study locations.

\begin{tabular}{|c|c|c|c|c|c|c|c|c|c|c|c|c|}
\hline \multirow[t]{3}{*}{ Variables/County } & \multicolumn{4}{|c|}{ Fairfield } & \multicolumn{4}{|c|}{ Hartford } & \multicolumn{4}{|c|}{ New Haven } \\
\hline & \multicolumn{4}{|c|}{2019} & \multicolumn{4}{|c|}{2019} & \multicolumn{4}{|c|}{2019} \\
\hline & $\mathbf{W}$ & Sp & $\mathbf{S}$ & $\mathbf{F}$ & $\mathbf{w}$ & Sp & $\mathbf{S}$ & $\mathbf{F}$ & $\mathbf{W}$ & SP & $\mathbf{S}$ & $\mathbf{F}$ \\
\hline Temp. $\left({ }^{\circ} \mathrm{C}\right)$ & -0.7 & 8.8 & 21.5 & 10.8 & -0.9 & 9.4 & 22.8 & 11.8 & 1.7 & 10.1 & 23.2 & 13.8 \\
\hline $\mathrm{RH}(\%)$ & 69.2 & 62.9 & 70.5 & 82.6 & 65.9 & 59.2 & 62.8 & 65.2 & 64.5 & 63.9 & 70.8 & 67.1 \\
\hline Wind speed $(\mathrm{km} / \mathrm{h})$ & \multicolumn{4}{|c|}{ Range from 7.5 to 10.3} & \multicolumn{4}{|c|}{ Range from 10.3 to 13.9} & \multicolumn{4}{|c|}{ Range from 9.2 to 12.9} \\
\hline WBGT $\left({ }^{\circ} \mathrm{C}\right)$ & -1.2 & 6.8 & 19.1 & 9.2 & -2.1 & 7.1 & 19.5 & 9.7 & 0.2 & 8.0 & 20.7 & 11.7 \\
\hline UTCI ( $\left.{ }^{\circ} \mathrm{C}\right)$ & -0.8 & 8.7 & 22.1 & 11.0 & -1.5 & 9.2 & 23.0 & 11.8 & 1.4 & 10.0 & 24.1 & 14.0 \\
\hline Variables & \multicolumn{4}{|c|}{2020} & \multicolumn{4}{|c|}{2020} & \multicolumn{4}{|c|}{2020} \\
\hline Temp. $\left({ }^{\circ} \mathrm{C}\right)$ & 1.1 & 8.7 & 22.1 & 12.2 & 1.1 & 9.4 & 23.1 & 12.7 & 3.3 & 10.0 & 23.4 & 14.7 \\
\hline $\mathrm{RH}(\%)$ & 67.5 & 60.3 & 72.1 & 74.4 & 64.9 & 54.3 & 63.1 & 68.5 & 67.2 & 62.4 & 73.8 & 72.4 \\
\hline Wind speed $(\mathrm{km} / \mathrm{h})$ & 9.6 & 11.9 & 8.1 & 8.0 & 12.1 & 15.6 & 11.2 & 11.8 & 11.2 & 13.4 & 9.7 & 10.9 \\
\hline WBGT $\left({ }^{\circ} \mathrm{C}\right)$ & -0.3 & 6.5 & 19.8 & 10.7 & -0.3 & 6.7 & 19.9 & 10.7 & 1.8 & 7.8 & 21.1 & 12.9 \\
\hline UTCI ( $\left.{ }^{\circ} \mathrm{C}\right)$ & 0.7 & 8.6 & 22.9 & 12.6 & 0.8 & 9.1 & 23.4 & 12.8 & 3.1 & 9.9 & 24.4 & 15.1 \\
\hline
\end{tabular}

W, Winter; SP, Spring; S, Summer; and F, Fall.

available for people that embrace the use of clean energy to promote the initiative at various levels.

Additionally, thorough assessments of the pre-pandemic activities that increased pollution rates and generated more carbon emissions in the study locations should be carried out. Policies that promote the development of infrastructures that reduce carbon emissions should be considered. Strategies that promote carbon credits for offices, businesses, and individuals for lowering carbon emissions should be explored. Strong partnerships between public and private organizations to support property owners in cities and towns to explore retrofit measures and renewable energy technologies, etc. should be encouraged. 
Also, policies that encourage people that their jobs permit them to work from home to reduce all non-essential travels should be promoted. Changes should be made to existing land-use guidelines in major cities to promote the effective use of green spaces. Sustainable urban fabric, gardens, and green walls should be promoted in urban areas to reduce the impact of UHI caused by climate change. Assessments of the outdoor environmental conditions between those periods should be also considered in most urban areas. Finally, the current research provides useful information for designers, planners, scientists, policymakers, and stakeholders, etc., on possible interventions that can provide pathways for attaining resilient zero-carbon cities in different locations.

\section{DATA AVAILABILITY STATEMENT}

The data supporting the conclusion of this article will be made available on request to the corresponding author.

\section{REFERENCES}

Adekunle, T. O. (2020). Occupants' comfort and Stress Indices in a Structural Timber School Building in the Northeast US in Different Seasons. Building Res. Inf. 48 (3), 331-348. doi:10.1080/09613218.2019.1662714

Adekunle, T. O. (2021). Thermal Performance and Apparent Temperature in School Buildings: A Case of Cross-Laminated Timber (CLT) School Development. J. Building Eng. 33, 101731. doi:10.1016/j.jobe.2020.101731

Adger, W. N., Brown, K., Nelson, D. R., Berkes, F., Eakin, H., Folke, C., et al. (2011). Resilience Implications of Policy Responses to Climate Change. Wires Clim. Change 2 (5), 757-766. doi:10.1002/wcc.133

Aitsi-Selmi, A., Egawa, S., Sasaki, H., Wannous, C., and Murray, V. (2015). The Sendai Framework for Disaster Risk Reduction: Renewing the Global Commitment to People's Resilience, Health, and Well-Being. Int. J. Disaster Risk Sci. 6 (2), 164-176. doi:10.1007/s13753-015-0050-9

Alkhalifa, F., Almurbati, N., Silva, J. P., and Wilkins, A. (2018). Visual Discomfort Health Concerns in the Future Cities of the Arabian Gulf: Case of Bahrain. Kls 4 (6), 128-138. doi:10.18502/kls.v4i6.3096

Alonso, A., Llanos, J., Escandón, R., and Sendra, J. J. (2021). Effects of the COVID-19 Pandemic on Indoor Air Quality and Thermal Comfort of Primary Schools in Winter in a Mediterranean Climate. Sustainability 13, 2699. doi:10.3390/su13052699

Aram, F., Solgi, E., Garcia, E. H., and Mosavi, A. (2020). Urban Heat Resilience at the Time of Global Warming: Evaluating the Impact of the Urban parks on Outdoor thermal comfort. Environ. Sci. Eur. 32, 117. doi:10.1186/s12302-020-00393-8

Bajšanski, I. V., Milošević, D. D., and Savić, S. M. (2015). Evaluation and Improvement of Outdoor thermal comfort in Urban Areas on Extreme Temperature Days: Applications of Automatic Algorithms. Building Environ. 94 (2), 632-643. doi:10.1016/j.buildenv.2015.10.019

Bosher, L. (2014). Built-in Resilience through Disaster Risk Reduction: Operational Issues. Building Res. Inf. 42 (2), 240-254. doi:10.1080/09613218.2014.858203

Chakraborty, T., and Lee, X. (2019). A simplified urban-extent algorithm to characterize surface urban heat islands on a global scale and examine vegetation control on their spatiotemporal variability. International Journal of Applied Earth Observation and Geoinformation 74, 269-280.

Chandra, A., Acosta, J., and Stern, S. (2010). Building Community Resilience to Disasters: A Way Forward to Enhance National Health Security. Santa Monica, CA: RAND Corporation.

Chen, L., and Ng, E. (2012). Outdoor thermal comfort and Outdoor Activities: a Review of Research in the Past Decade. Cities 29 (2), 118-125. doi:10.1016/ j.cities.2011.08.006

Chepesiuk, R. (2005). Decibel Hell: the Effects of Living in a Noisy World. Environ. Health Perspect. 113113 (1), A34-A41. doi:10.1289/ehp.113-a34

\section{AUTHOR CONTRIBUTIONS}

The author confirms being the sole contributor of this work and has approved it for publication.

\section{ACKNOWLEDGMENTS}

The author would like to appreciate the Zero Carbon Lab team for organizing the Pathways to Resilient Zero Carbon Cities (RZCC) 2021 where a portion of the research outcomes was first presented.

\section{SUPPLEMENTARY MATERIAL}

The Supplementary Material for this article can be found online at: https://www.frontiersin.org/articles/10.3389/fbuil.2021.765752/ full\#supplementary-material

Cheshmehzangi, A. (2020). "Preparedness through Urban Resilience," in The City in Need: Urban Resilience and City Management in Disruptive Disease Outbreak Events, 41-103. doi:10.1007/978-981-15-5487-2_3

Climate Central (2014). Appendix B: Satellite Surface Temperature Images. Available at: http://assets.climatecentral.org/pdfs/UHI-AppendixB.pdf. [Accessed October 2021].

Davoudi, S., Shaw, K., Haider, L. J., Quinlan, A. E., Peterson, G. D., Wilkinson, C., et al. (2012). Resilience: A Bridging Concept or a Dead End? "Reframing" Resilience: Challenges for Planning Theory and Practice Interacting Traps: Resilience Assessment of a Pasture Management System in Northern Afghanistan Urban Resilience: What Does it Mean in Planning Practice? Resilience as a Useful Concept for Climate Change Adaptation? the Politics of Resilience for Planning: A Cautionary Note. Plann. Theor. Pract. 13 (2), 299-333. doi:10.1080/14649357.2012.677124

de Paiva Vianna, K., Rodrigues, R. M., and Alves Cardoso, M. (2015). Noise Pollution and Annoyance: an Urban Soundscapes Study. Noise Health 17 (76), 125-133. doi:10.4103/1463-1741.155833

Djongyang, N., Tchinda, R., and Njomo, D. (2010). Thermal comfort: a Review Paper. Renew. Sust. Energ. Rev. 14 (9). doi:10.1016/j.rser.2010.07.040

Dwyer, A., Zoppou, C., Nielsen, O., Day, S., and Roberts, S. (20042004). Quantifying Social Vulnerability: a Methodology for Identifying Those at Risk to Natural Hazards. Geosci. Aust. Rec. 37, 101189. doi:10.1016/j.ijdrr.2019.101189

Eken, C. (2019). Learning from Resilience: Cities towards a Self-Organizing System. Jcua 3 (1), 92-103. doi:10.25034/ijcua.2018.4686

Emmanuel, R. (2005). Thermal comfort Implications of Urbanization in a WarmHumid City: the Colombo Metropolitan Region (CMR), Sri Lanka. Building Environ. 40 (12), 1591-1601. doi:10.1016/j.buildenv.2004.12.004

Environmental Health (2021). As Temperature Set Records, Heat Exposure Hits Some Neighborhoods Harder Than Others. Boston: Boston University. Available at: https:/www.bu.edu/articles/2021/heat-exposure-hits-vulnerablecommunities-harder-than-others/(Accessed October, 2021).

EPA (2020b). Air Quality - Cities and Counties. Washington, DC: United States Environmental Protection Agency. (EPA). Available at: https://www.epa.gov/ air-trends/air-quality-cities-and-counties (Accessed April, 2021).

EPA (2020a). Learn about Heat Islands. Washington, DC: United States Environmental Protection Agency. (EPA). Available at: https://www.epa.gov/ heatislands/learn-about-heat-islands (Accessed April, 2021).

EPA (2021). Measuring Heat Islands. Washington, DC: United States Environmental Protection Agency. (EPA). Available at: https://www.epa.gov/ heatislands/measuring-heat-islands (Accessed October, 2021).

EPA (2001). The United States Experience with Economic Incentives for Protecting the Environment. Washington, DC: United States Environmental Protection Agency. (EPA). 
Fanger, P. O. (1973). Assessment of Man's thermal comfort in Practice. Occup. Environ. Med. 30 (4), 313-324. doi:10.1136/oem.30.4.313

Federal Register (2012). Rules and Regulations. Monday 77, 199, 2012 . October 15, 2012.

Gagge, A. P., Fobelets, A. P., and Berglund, L. G. (1986). Standard Predictive index of Human Response to the thermal Environment. ASHRAE Trans. 92 (pt 2B), 709-731.

Gago, E. J., Roldan, J., Pacheco-Torres, R., and Ordóñez, J. (2013). The City and Urban Heat Islands: A Review of Strategies to Mitigate Adverse Effects. Renew. Sust. Energ. Rev. 25, 749-758. doi:10.1016/j.rser.2013.05.057

Godschalk, D. R. (2003). Urban Hazard Mitigation: Creating Resilient Cities. Nat. Hazards Rev. 4 (3), 136-143. doi:10.1061/(asce)1527-6988(2003)4:3(136)

Gout, E., and Kelly, C. (2020). Extreme heat during the COVID-19 pandemic amplifies racial and economic inequalities. Energy and Environment, Center for American Progress. Available at: https://www.americanprogress.org/issues/ green/news/2020/06/29/486959/extreme-heat-covid-19-pandemic-amplifiesracial-economic-inequities/. [Accessed October, 2021].

Höppe, P. (1999). The Physiological Equivalent Temperature - a Universal index for the Biometeorological Assessment of the thermal Environment. Int. J. Biometeorology 43 (2), 71-75. doi:10.1007/s004840050118

Intergovernmental Panel on Climate Change (IPCC) (2018). Special Report: Global Warming of $1.5^{\circ} \mathrm{C}$. Available at: https://www.ipcc.ch/sr15/. [Accessed October, 2021].

IPCC (2019). Special Report on Climate Change and Land. The Intergovernmental Panel on Climate Change (IPCC). Available at: https://www.ipcc.ch/report/ srccl/. [Accessed April 2021]

Jendritzky, G., Havenith, G., Weihs, P., and Batchvarova, E. (2009). Towards a Universal Thermal Climate Index UTCI for Assessing the thermal Environment of the Human Being. In: Final report COST Action 730. Available at: https://www.utci.org/cost/documents.php. [Accessed April 2021]

Kenward, A., Yawtiz, D., Sanford, T., and Wang, R. (2014). Summer in the City: Hot and Getting Hotter. Climate Central. Princeton, NJ. Available at: http:// assets.climatecentral.org/pdfs/UrbanHeatIsland.pdf (Accessed October, 2021).

Klein, R. J. T., Nicholls, R. J., and Thomalla, F. (2003). Resilience to Natural Hazards: How Useful Is This Concept. Environ. Hazards 5 (1), 35-45. doi:10.1016/j.hazards.2004.02.001

Kottek, M., Grieser, J., Beck, C., Rudolf, B., and Rubel, F. (2006). World Map of the Köppen-Geiger Climate Classification Updated. metz 15 (3), 259-263. http://koeppen-geiger.vu-wien.ac.at/present.htm. doi:10.1127/0941-2948/ 2006/0130

Lau, K. K.-L., Chung, S. C., and Ren, C. (2019). Outdoor thermal comfort in Different Urban Settings of Sub-tropical High-Density Cities: An Approach of Adopting Local Climate Zone (LCZ) Classification. Building Environ. 154, 227-238. doi:10.1016/j.buildenv.2019.03.005

Luber, G., and McGeehin, M. (2008). Climate Change and Extreme Heat Events. Am. J. Prev. Med. 35 (5), 429-435. doi:10.1016/j.amepre.2008.08.0210.1016/ j.amepre.2008.08.021

Mahmoud, S. H., and Gan, T. Y. (2018). Impact of Anthropogenic Climate Change and Human Activities on Environment and Ecosystem Services in Arid Regions. Sci. Total Environ. 633, 1329-1344. doi:10.1016/ j.scitotenv.2018.03.290

Manyena, S. B. (2006). The Concept of Resilience Revisited. Disasters 30 (4), 433-450. doi:10.1111/j.0361-3666.2006.00331.x

Martin, S. A. (2015). A Framework to Understand the Relationship between Social Factors that Reduce Resilience in Cities: Application to the City of Boston. Int. J. Disaster Risk Reduction 12, 53-80. doi:10.1016/j.ijdrr.2014.12.001

Meerow, S., and Newell, J. P. (2016). Urban Resilience for Whom, what, when, where, and Why?. Urban Geogr. 40 (3), 1-21. Geographic Perspectives on Urban Sustainability.

Monstadt, J. (2009). Conceptualizing the Political Ecology of Urban Infrastructures: Insights from Technology and Urban Studies. Environ. Plan. A. 41 (8), 1924-1942. doi:10.1068/a4145

National Geographic Society (2021). Human Impacts on the Environment. Available at: https://www.nationalgeographic.org/topics/resource-libraryhuman-impacts-environment/. [Accessed October 2021].

NHTSA (National Highway Traffic Safety Administration) and EPA (2020). The Safer Affordable Fuel-Efficient (SAFE) Vehicles Rule for Model Years 2021-2026 Passenger Cars and Light Trucks, Final Rule. Fed. Regist. 85, 84.
Nikolopoulou, M., and Lykoudis, S. (2006). Thermal comfort in Outdoor Urban Spaces: Analysis across Different European Countries. Building Environ. 41 (11), 1455-1470. doi:10.1016/j.buildenv.2005.05.031

OSHA (2020). COVID-19 Guidance on the Use of Cloth Face Coverings while Working Outdoors in Hot and Humid Conditions. The Occupational Safety and Health Administration. Available at: https://www.osha.gov/ sites/default/files/covid-19-cloth-coverings-outdoor-heat.pdf. [Accessed October 2021].

Plough, A., Fielding, J. E., Chandra, A., Williams, M., Eisenman, D., Wells, K. B., et al. (2013). Building Community Disaster Resilience: Perspectives from a Large Urban County Department of Public Health. Am. J. Public Health 103 (7), 1190-1197. doi:10.2105/ajph.2013.301268

Potchter, O., Cohen, P., Lin, T.-P., and Matzarakis, A. (2018). Outdoor Human thermal Perception in Various Climates: a Comprehensive Review of Approaches, Methods and Quantification. Sci. Total Environ. 631-632, 390-406. doi:10.1016/j.scitotenv.2018.02.276

Rupp, R. F., Vásquez, N. G., and Lamberts, R. (2015). A Review of Human thermal comfort in the Built Environment. Energy and Buildings 105, 178-205. doi:10.1016/j.enbuild.2015.07.047

Saraoui, S., Belakehal, A., Attar, A., and Bennadji, A. (2018). Evaluation of the Thermal Comfort in the Design of the Museum Routes: The Thermal Topology. Jcua 2 (3), 122-136. doi:10.25034/ijcua.2018.4727

Torrey, B. B. (2004). Urbanization: an Environmental Force to Be Reckoned with". Population Reference Bureau. Available at: https://www.prb.org/urbanizationan-environmental-force-to-be-reckoned-with/. [Accessed March, 2021].

UN (2020). Everyone Included: Social Impact of COVID-19. United Nations Department of Economic and Social Affairs. Social Inclusion. Available at: https://www.un.org/development/desa/dspd/everyone-included-covid-19. html. [Accessed April 2021].

UNISDR (2012). How to Make Cities More Resilient - a Handbook for Local Government Leaders". A Contribution to the Global Campaign 20102015. The United Nations Office for Disaster Risk Reduction (UNISDR). Geneva March 2012. Available from: http://164.125.174.23:8080/lee/How \%20To\%20Make\%20Cities\%20More\%20Resilient.pdf (Accessed April, 2021).

United Nations (UN) (1992). United Nations Framework Convention on Climate Change (UNFCCC).

US Census Bureau (2013). Growth in Urban Population Outpaces Rest of Nation, Census Bureau Reports. Census.gov. Available at: http://www.census.gov/ newsroom/releases/archives/2010_census/cb12-50.html. [Accessed March 2021].

US Census Bureau 2021. QuickFacts. Available at: https://www.census.gov/ quickfacts. [Accessed April 2021].

Ward, K., Lauf, S., Kleinschmit, B., and Endlicher, W. (2016). Heat Waves and Urban Heat Islands in Europe: a Review of Relevant Drivers. Sci. Total Environ. 569-570 (570), 527-539. doi:10.1016/j.scitotenv.2016.06.119

WHO (2020). Impact of COVID-19 on People's Livelihoods, Their Health and Our Food Systems. Joint statement by ILO, FAO, IFAD and WHO. Available at: https://www.who.int/news/item/13-10-2020-impact-of-covid-19-on-people'slivelihoods-their-health-and-our-food-systems. [Accessed April 2021].

Yilmaz, D. G. (2021). Model Cities for Resilience: Climate-Led Initiatives. Jcua 5 (1), 47-58. doi:10.25034/ijcua.2021.v5n1-4

Conflict of Interest: The authors declare that the research was conducted in the absence of any commercial or financial relationships that could be construed as a potential conflict of interest.

Publisher's Note: All claims expressed in this article are solely those of the authors and do not necessarily represent those of their affiliated organizations, or those of the publisher, the editors and the reviewers. Any product that may be evaluated in this article, or claim that may be made by its manufacturer, is not guaranteed or endorsed by the publisher.

Copyright (๑) 2021 Adekunle. This is an open-access article distributed under the terms of the Creative Commons Attribution License (CC BY). The use, distribution or reproduction in other forums is permitted, provided the original author $(s)$ and the copyright owner(s) are credited and that the original publication in this journal is cited, in accordance with accepted academic practice. No use, distribution or reproduction is permitted which does not comply with these terms. 